\begin{tabular}{|c|c|c|}
\hline BIODIK & $\begin{array}{c}\text { BIODIK: Jurnal IImiah Pendidikan Biologi } \\
\text { ISSN 2580-0922 (online), ISSN 2460-2612 (print) } \\
\text { Volume 7, Nomor 02, Tahun 2021, Hal. 196-204 } \\
\text { Available online at: } \\
\text { https://online-journal.unja.ac.id/biodik }\end{array}$ & \begin{tabular}{l|l} 
BIODIK & $(Q)$
\end{tabular} \\
\hline
\end{tabular}

Research Article

OPEN ACCESS

\title{
Pembelajaran Process Oriented Guided Inquiry Learning (POGIL) diintegrasikan Discovery Learning untuk Meningkatkan Kemampuan Berpikir Analisis Peserta Didik
}

\section{(Process Oriented Guided Inquiry Learning (POGIL) integrated with Discovery Learning to improve students' analytical thinking skills)}

Calvin Talakua*, Marlen Sahureka

Program Studi Pendidikan Biologi, Jurusan MIPA, STKIP Gotong Royong Masohi JIn. Transeram Belakang Negeri Haruru, Kota Masohi Kabupaten Maluku Tengah

${ }^{*}$ Corresponding Author : talakua_calvin@yahoo.co.id

\begin{tabular}{|c|c|}
\hline Informasi Artikel & ABSTRACT \\
\hline $\begin{array}{l}\text { Submit: } 16-03-2021 \\
\text { Diterima: } 29-05-2021 \\
\text { Dipublikasikan: } 15-06-2021\end{array}$ & $\begin{array}{l}\text { This research was conducted based on the results of initial observations } \\
\text { through interviews with Biology subject teachers for class X at Trana Christian } \\
\text { High School, it was found that the implementation of the } 2013 \text { curriculum in } \\
\text { schools had not been going well, because teachers often used lecture } \\
\text { methods, and discussions in the learning process. This affects the analytical } \\
\text { thinking ability of students. The purpose of this study was to determine the } \\
\text { analytical thinking ability of students of class X MIA Christian High School } \\
\text { Trana through Process Oriented Guided Inquiry Learning (POGIL) and } \\
\text { Discovery Learning on the Classification of Living Things. This type of research } \\
\text { is descriptive qualitative research, with the research subjects are all students of } \\
\text { class X MIA Christian High School Trana, totaling } 23 \text { people. Data collection } \\
\text { techniques used in this study were observation sheets, tests, questionnaires, } \\
\text { and documentation.The results showed that the analytical thinking skills of } 23 \\
\text { students of class X MIA Christian High School Trana through the integration of } \\
\text { POGIL learning and Discovery Learning obtained an average total score } \\
\text { presentation of } 80 \% \text { of students in the good category, and } 20 \% \text { in the fairly } \\
\text { good category. } \\
\text { Key words: Analytical Thinking Ability, POGIL, Discovery Learning }\end{array}$ \\
\hline Penerbit & ABSTRAK \\
\hline $\begin{array}{l}\text { Program Studi Pendidikan Biologi } \\
\text { FKIP Universitas Jambi, } \\
\text { Jambi- Indonesia }\end{array}$ & $\begin{array}{l}\text { Penelitian ini dilakukan berdasarkan hasil observasi awal melalui wawancara } \\
\text { dengan guru mata pelajaran Biologi kelas X di SMA Kristen Trana diketahui } \\
\text { bahwa, penerapan kurikulum } 2013 \text { di sekolah belum berjalan dengan baik, } \\
\text { dikarenakan guru sering menggunakan metode ceramah, dan diskusi dalam } \\
\text { proses pembelajaran. Hal ini berpengaruh pada kemampuan berpikir analisis } \\
\text { peserta didik. Tujuan penelitian ini adalah untuk mengetahui kemampuan } \\
\text { berpikir analisis peserta didik kelas X MIA SMA Kristen Trana melalui } \\
\text { pembelajaran Process Oriented Guided Inquiry Learning (POGIL) dan } \\
\text { Discovery Learning pada materi Klasifikasi Makhluk Hidup. Jenis penelitian ini } \\
\text { adalah penelitian deskriptif kualititatif, dengan subjek penelitian adalah seluruh } \\
\text { peserta didik kelas X MIA SMA Kristen Trana yang berjumlah } 23 \text { orang. Teknik } \\
\text { pengumpulan data yang digunakan dalam penelitian ini adalah lembar } \\
\text { observasi, tes, penyebaran angket, dan dokumentasi. Hasil Penelitian } \\
\text { menunjukan bahwa kemampuan berpikir analisis dari } 23 \text { peserta didik kelas X } \\
\text { MIA SMA Kristen Trana melalui integrasi pembelajaran POGIL dan Discovery } \\
\text { Learning memperoleh rata-rata presentasi skor total peserta didik } 80 \% \text { dengan } \\
\text { kategori baik, dan } 20 \% \text { berada pada kategori cukup baik. } \\
\text { Kata kunci: Kemampuan Berpikir Analisis, POGIL dan Discovery Learning }\end{array}$ \\
\hline
\end{tabular}




\section{PENDAHULUAN}

Pembelajaran biologi dikembangkan melalui kemampuan berpikir analitis, induktif, dan deduktif untuk menyelesaikan masalah yang berkaitan dengan kehidupan sehari -hari (Normaya, 2015). Hal tersebut sesuai dengan tujuan pembelajaran IPA SMA untuk mencari tahu, dan menemukan sendiri, sehingga dapat membantu peserta didik memperoleh pengalaman yang lebih mendalam tentang alam sekitar ( Kadri, 2015). Dalam pembelajaran biologi, peserta didik tidak hanya sekedar menghafal, tetapi meminta peserta didik untuk berpikir tingkat tinggi, salah satunya dengan berpikir analitis, (Harsanto,2007). Pengembangan aspek - aspek pembelajaran biologi, seperti pengertahuan, moral, akhlak, perilaku, dan ketrampilan diwujudkan dengan perlakuan kurikulum 2013.

Kurikulum 2013 lebih dominan atau memiliki kecenderungan pada paradigma teori pembelajaran konstruktivisme (Yuliati, 2013). Teori Konstruktivisme dalam pembelajaran merupakan ide-ide atau gagasan yang mengharuskan peserta didik sendiri untuk mengamati dan menemukan selanjutnya ditransformasikan serta diinterpretasikan sendiri suatu informasi. Salah satu pembelajaran yang mengarahkan peserta didik untuk mengkontruksikan pengetahuannya sendiri dengan melibatkan peserta didik secara aktif adalah Process Oriented Guided Inquiry Learning (POGIL) (Sen danYilmaz, 2015). POGIL adalah sebuah pendekatan instruksional yang menggabungkan inkuiri terbimbing dan pembelajaran kooperatif dimana peserta didik terlibat dalam proses pembelajaran sehingga membantu mereka untuk mengembangkan keterampilan belajar mandiri. Perpaduan pembelajaran kooperatif dan aktivitas penyelidikan terbimbing dalam pembelajaran POGIL memberi kesempatan kepada peserta didik untuk aktif dalam kelompok diskusi untuk mengkontruksi pemahaman mereka (Maulidiawati dan Soeprojo, 2015).

Hanson dan Moog (2016), menyatakan pembelajaran POGIL meningkatkan persepsi peserta didik tentang pentingnya kerja kelompok, tentang pentingnya rekan-rekan mereka dalam membantu mereka untuk memahami konsep-konsep. Selain itu menurut Simonson (2015), peserta didik yang belajar dengan kegiatan POGIL lebih terkoordinasi dan kooperatif dalam membangun dan memahami konsep dengan baik. Kegiatan POGIL tidak hanya meningkatkan interaksi peserta didik dengan materi, tetapi juga peserta didik dengan teman, peserta didik dengan guru, meningkatkan keterlibatan peserta didik, serta mendorong retensi pengetahuan, kemampuan berpikir tingkat tinggi dan ketrampilan aplikasi peserta didik. Adapun kelemahan POGIL antara lain kurangnya kesempatan peserta didik dalam melaksanakan eksperimen sendiri, tidak punya kesempatan berpikir berdasarkan kemampuannya, dan kurang kritis (Moog dan Specer, 2015).

Untuk mengantisipasi kelemahan pembelajaran POGIL dapat diterapkan model pembelajaran Discovery Learning. Model ini mengatur pengajaran sedemikian rupa sehingga peserta didik berusaha sendiri untuk mencari pemecahan masalah. Pembelajaran Discovery Learning mengharapkan peserta didik dapat menemukan konsep-konsep dan prinsip-prinsip melalui proses mentalnya sendiri. Dalam menemukan konsep, peserta didik melakukan pengamatan, menggolongkan, membuat dugaan, 
menjelaskan, menarik kesimpulan dan sebagainnya untuk menemukan beberapa konsep atau prinsip dengan demikian mengasah kemampuan analitis dan berpikir kritis peserta didik (Taslin, 2016).

Menurut Sani (2015) Discovery Learning adalah metode belajar yang menuntut guru lebih kreatif menciptakan situasi yang membuat peserta didik belajar aktif dan lebih kritis menemukan pengetahuan sendiri. Penyampaian materi pada proses pembelajaran Discovery Learning tidak utuh, karena model ini menuntut peserta didik terlibat aktif dalam proses pembelajaran dan menemukan sendiri suatu konsep pembelajaran (Maharani dan Hardini, 2018). Perpaduan pembelajaran Discovery Learning dengan model pembelajaran POGIL, akan lebih banyak memberikan kesempatan peserta didik untuk berpikir dan menyampaikan pendapat, yang berimplikasi terhadap kemampuan peserta didik berpikir analisis.

Berdasarkan hasil wawancara dengan guru mata pelajaran Biologi kelas X di SMA Kristen Trana tanggal 05 Mei 2020 diketahui bahwa, penerapan kurikulum 2013 disekolah belum berjalan dengan baik, dikarenakan guru sering menggunakan metode ceramah, dan diskusi dalam proses pembelajaran. Kurangnya ketrampilan guru dalam memvariasi model-model pembelajaran sehingga membuat peserta didik menjadi jenuh dalam menerima pelajaran.Hal ini juga menyebabkan kemampuan peserta didik dalam menyelesaikan soal -soal biologi dengan tingkat kualitas tinggi kurang baik. Salah satu materi biologi yang membutuhkan kemampuan analitis adalah klasifikasi makhluk hidup. Pada materi ini kemampuan analisis peserta didik sangat dibutuhkan sehingga dapat melakukan pengelompokan makhluk hidup berdasarkan ciri yang diamati, pemberian nama makhluk hidup, dan pengamatan sifat makhluk hidup.

\section{METODE PENELITIAN}

Pada penelitian ini digunakan pendekatan deskriptif kualitatif. Penelitian ini akan dilakukan di SMA Kristen Trana. Subjek penelitian ini adalah seluruh peserta didik kelas X MIA SMA Kristen Trana. Teknik pengumpulan data yang digunakan dalam penelitian ini adalah lembar observasi, tes, penyebaran angket, dan dokumentasi. Analisis data digunakan untuk mengetahui kemampuan berpikir analisis peserta didik. Analisis dilakukan terhadap data yang bersifat kuantitatif, yang diperoleh melalui tes kemampuan berpikir analisis peserta didik. Untuk mengetahui kemampuan berpikir analisis peserta didik dari tiap indikator, maka dihitung persentase setiap skornya menggunakan rumus:

$$
P S=\frac{B T}{N} X 100 \%
$$

dimana:

$$
\begin{aligned}
& \mathrm{PS}=\text { Persentase kemampuan analisis tiap skor } \\
& \mathrm{BT}=\text { Banyak peserta didik yang menjawab soal tiap indikator } \\
& \mathrm{n}
\end{aligned}
$$

Selain itu, dilakukan analisis terhadap kemampuan analisis peserta didik dengan cara melihat persentase tiap skor total yang diperoleh peserta didik dan dihitung menggunakan rumus:

$$
P K=\frac{J S}{J M} X 100
$$

dimana:

PK = Persentase kemampuan analisispeserta didik

JS = Jumlah skor total peserta didik 
$\mathrm{JM}=$ Jumlah skor total maksimum

Untuk keperluan mengklarifikasi kualitas kemampuan berpikir analisis peserta didik dikelompokkan menjadi kategori sangat baik, baik, cukup, kurang, dan sangat kurang dengan menggunakan kategori presentase ketrampilan berpikir analisis menurut Arikunto dkk, ( 2018 ) yaitu sebagaimana dapat dilihat pada tabel 1.

Tabel 1. Kriteria Penentuan Tingkat Kemampuan Berpikir Analisis Peserta Didik

\begin{tabular}{cll}
\hline Presentase Skor Total Peserta Didik & $\begin{array}{l}\text { Kategori Kemampuan Berpikir Analisis } \\
\text { Peserta Didik }\end{array}$ \\
\hline $81 \% \leq \mathrm{A} \leq 100 \%$ & Sangat Baik \\
\hline $61 \% \leq \mathrm{B} \leq 80 \%$ & Baik \\
\hline $41 \% \leq \mathrm{C} \leq 60 \%$ & Cukup \\
\hline $21 \% \leq \mathrm{D} \leq 40 \%$ & Kurang \\
\hline $0 \% \leq \mathrm{E} \leq 20 \%$ & Sangat Kurang \\
\hline
\end{tabular}

\section{HASIL PENELITIAN DAN PEMBAHASAN}

Penelitian ini dilakukan pada peserta didik kelas X MIA SMA Kristen Trana pada tahun pelajaran 2020/2021. Dalam penelitian ini dipadukan dua model pembelajaran yaitu POGIL dan Discovery Learning. Karakteristik subjek berdasarkan umur dapat di lihat pada tabel 2.

Tabel 2. Karakteristik Subjek Penelitian Berdasarkan Umur

\begin{tabular}{ccc}
\hline No & Umur & Frekuensi \\
\hline 1 & 15 Tahun & 8 \\
\hline 2 & 16 Tahun & 11 \\
\hline 3 & 17 Tahun & 4 \\
\hline & Total & 23 \\
\hline
\end{tabular}

Berdasarkan tabel 2 menunjukan bahwa subjek penelitian yang berumur 15 tahun berjumlah 8 orang, 16 tahun berjumlah 11 orang, dan 17 tahun berjumlah 4 orang. Karakteristik Subjek penelitian berdasarkan jenis kelamin terdiri darei 8 orang laki-laki, dan 15 orang perempuan yang totalnya 23 orang siswa. Jumlah itu dapat dilihat pada tabel 3.

Tabel 3. Karakteristik Subjek Penelitian Berdasarkan JenisKelamin

\begin{tabular}{cc}
\hline Jenis Kelamin & Frekuensi \\
\hline Laki-Laki & 8 \\
\hline Perempuan & 15 \\
\hline Total & 23 \\
\hline
\end{tabular}

Lebih lanjut, Hasil tes kemampuan berpikir analisis peserta didik kelas X MIA SMA Kristen Trana dapat di lihat pada tabel 4. Berdasarkan tabel 4, menunjukan bahwa subjek penelitian yang memperoleh kriteria baik berjumlah 17 orang, sedangkan yang memperoleh kriteria cukup baik berjumlah 6 orang. Jumlah skor tertinggi 79 dan memperoleh kriteria baik adalah peserta didik HW , dengan nilai aspek mengemukakan pertanyaan terkait masalah adalah 3 , aspek merumuskan tujuan 
adalah 2, aspek menggunakan informasi berupa data, fakta, observasi, dan percobaan adalah 2, aspek membuat asumsi adalah 2, aspek mengimpilikasi adalah 2, aspek menggunakan konsep adalah 3 , aspek menggunakan refrensi atau wacana adalah 3 , aspek membuat kesimpulan adalah 1.

Tabel 4. Hasil Tes Kemampuan Berpikir Analisis

\begin{tabular}{clcc}
\hline No & Nama Siswa & Jumlah Skor & Kriteria \\
\hline $\mathbf{1}$ & AYN & 75 & Baik \\
\hline $\mathbf{2}$ & AP & 66 & Baik \\
\hline $\mathbf{3}$ & BR & 58 & Cukup Baik \\
\hline $\mathbf{4}$ & CMK & 66 & Baik \\
\hline $\mathbf{5}$ & CS & 70 & Baik \\
\hline $\mathbf{6}$ & FB & 70 & Baik \\
\hline $\mathbf{7}$ & GJ & 62 & Baik \\
\hline $\mathbf{8}$ & GW & 75 & Baik \\
\hline $\mathbf{9}$ & HPM & 70 & Baik \\
\hline 10 & HP & 58 & Cukup Baik \\
\hline 11 & HW & 79 & Baik \\
\hline 12 & JS & 50 & Cukup Baik \\
\hline 13 & LT & 62 & Baik \\
\hline 14 & LM & 62 & Baik \\
\hline 15 & NM & 58 & Cukup Baik \\
\hline 16 & PMS & 75 & Baik \\
\hline 17 & PO & 70 & Baik \\
\hline 18 & RP & 45 & Cukup Baik \\
\hline 19 & RW & 75 & Baik \\
\hline $\mathbf{2 0}$ & SW & 70 & Baik \\
\hline $\mathbf{2 1}$ & SP & 50 & Cukup Baik \\
\hline $\mathbf{2 2}$ & YP & 62 & Baik \\
\hline $\mathbf{2 3}$ & YT & 62 & Baik \\
\hline & & & \\
\hline
\end{tabular}

Sedangkan subjek penelitian yang memperoleh jumlah skor terrendah 45 dan memperoleh kriteria cukup baik adalah peserta didik RP, dengan nilai aspek mengemukakan pertanyaan terkait masalah adalah 3, aspek merumuskan tujuan adalah 2, aspek menggunakan informasi berupa data, fakta, observasi, dan percobaan adalah 0 , aspek membuat asumsi adalah 0 , aspek mengimpilikasi adalah 1, aspek menggunakan konsep adalah 2, aspek menggunakan refrensi atau wacana adalah 2, aspek membuat kesimpulan adalah 1. Hasil observasi kemampuan berpikir analisis peserta didik kelas X MIA SMA Kristen Trana dapat di lihat pada tabel 5.

Tabel 5. Hasil Observasi Kemampuan Berpikir Analisis

\begin{tabular}{cccc}
\hline No & Rentang Skor & Kriteria & Frekuensi \\
\hline 1 & $41-60$ & Cukup Baik & 6 \\
\hline 2 & $61-80$ & Baik & 17 \\
\hline \multicolumn{5}{c}{ Total } & \\
\hline
\end{tabular}

Berdasarkan tabel 5 menunjukan bahwa subjek penelitian yang memperoleh skor rentang 4160 dengan kriteria cukup baik berjumlah 6 orang dan yang memperoleh skor rentang 40-60 dengan kriteria baik berjumlah 17 orang. Persepsi peserta didik kelas X MIA SMA Kristen Trana terhadap penerapan model pembelajaran POGIL dan Discovery Learning dapat di lihat pada tabel 6. 
Tabel 6. Hasil Angket Peserta Didik

\begin{tabular}{|c|c|c|}
\hline Rentang Skor & Kriteria & Frekuensi \\
\hline $41-60$ & Cukup Setuju & 3 \\
\hline $61-80$ & Setuju & 15 \\
\hline $81-100$ & Sangat Setuju & 5 \\
\hline \multicolumn{2}{|c|}{ Total } & 23 \\
\hline
\end{tabular}

Berdasarkan tabel 7 ,menunjukan bahwa subjek penelitian yang memberikan jawaban sangat setuju dengan rentang skor 61-80 berjumlah 15 orang, yang memberikan jawaban setuju dengan rentang skor $81-100$ berjumlah 5 orang, dan yang memberikan jawaban cukup setuju dengan rentang skor 41-60 berjumlah 3 orang.

Berdasarkan hasil tes kemampuan berpikir analisisdiperoleh nilai tertinggi adalah 79 dengan kriteria baik dan nilai terendah 45 dengan kriteria cukup baik. Hal ini menunjukan bahwa dengan penerapan model pembelajaran POGIL dan Discovery Learningadalah baik dan cukup baik. Tahapan POGIL membuat peserta didik mampu menemukan konsep dibantu dengan bimbingan guru sedangkan tahapan Discovery Learningpeserta didik menemukan konsep secara mandiri sehingga kedua pembelajaran ini mampu untuk mengembangkan kemampuan berpikir analisis peserta didik (Rusdi, 2018).

Model pembelajaran POGIL merupakan salah satu model pembelajaran jenis inkuiri yang memberikan kesempatan bagi guru untuk mengajarkan konten pembelajaran dan ketrampilan, proses secara bersamaan. Tujuan dari implementasi POGIL di kelas adalah membuat peserta didik bertanggung jawab untuk membangun pengertiannya sendiri dalam belajar (Moog dan Spencer,2015). Menurut, De Gale (2012) POGIL adalah teknik pembelajaran kolaboratif yang menggunakan inkuiri terbimbing yang di dalamnya terdapat sebuh sistem yang saling berhubungan yaitu, eksplorasi, penemuan konsep dan aplikasi. POGIL menekankan bahwa belajar adalah proses interaktif dalam berpikir dengan saksama, mendiskusikan ide-ide menyempurnakan pemahaman, melatih ketrampilan, dan merefleksikan penigkatan pembelajaran. POGIL berpengaruh terhadap kemampuan berpikir analisis peserta didik karena POGIL merupakan strategi pembelajaran aktif yang menggunakan belajar dalam tim dengan aktivitas guided inkuiry (Hatson, 2015). Peserta didik menenmukan jawaban dari kasus pada materi klasifikasi makhluk hidup berkaitan dengan kehidupan sehari-hari yang diberikan oleh guru melalui berbagai sumber.

Ditahap eksplorasi, peserta didik memecahkan kasus klasifiaksi makhluk hidup yang diberikan dalam pertanyaan dilembar kerja siswa (LKS). Dapat mengembangkan kemampuan berpikir analisis (Hatson, 2015). Masalah yang di berikan di LKS berkaitan dengan kehidupan sehari-hari (Ningsih, 2016). Selama mencari jawaban dari berbagai sumber peserta didik mengembangkan kemampuan berpikir analisis mereka untuk memecahkan masalah yang ada di LKS. Siswa menemukan sendiri (inkuiri) jawaban dari informasi yang di peroleh.

Hal ini sejalan dengan penelitian Rosida (2016) bahwa POGIL berbantuan LKS efektif terhadap kemampuan pemecahan masalah Biologi materi klasifikasi makhluk hidup pada peserta didik kelas $\mathrm{X}$ MIA SMA Kristen Trana. Sulastriningsih dan Suranata (2014) mengatakan bahwa guru hanya berperan sebagai pembimbing dalam proses pembelajaran. Ditahap penemuan konsep ini guru mengajukan pertanyaan yang menuntun peserta didik untuk mengembangan kemampuan berpikir analisis peserta 
didik. Kemampuan berpikir analisis peserta didik semakin terasa setelah memasuki tahap aplikasi. Setelah peserta didik memiliki konsep, peserta didik mengaplikasikan konsep dengan mangaitkannya kedalam kehidupan sehari-hari. Sedangkan model pembelajaran discovery learning merupakan model yang mengarahkan peserta didik menemukan konsep melalui berbagai informasi atau data yang di peroleh melalui pengamatan atau percobaan. Menurut Sani (2014) discovery learning merupakan proses dari inkuiri. Discovery learning adalah proses pembelajaran yang penyampaian materinya tidak utuh, karena model discovery learning menuntut peserta didik terlibat aktif dalam proses pembelajaran dan menemukan sendiri suatu konsep pembelajaran.

Menurut H. Malik (2014) discovery learning adalah proses pembelajaran yang menitik beratkan pada mental intelektual peserta didik dalam memecahkan berbagai persoalan yang dihadapi, sehingga menemukan suatu konsep atau generalisasi yang dapat di terapkan di lapangan.Discovery learning yang di maksud adalah pembelajaran yang mengajak peserta didik untuk memecahkan suatu permasalahan melalui pengamatan atau percobaan agar dapat menemukan kesimpulan atau konsep.

Discovery learning meningkatkan kemampuan berpikir analisis peserta didik. Hal ini di sebabkan karena pada discovery learning peserta didik mampu mengasimilasikan konsep yang ia dapatkan sendiri dari berbagai sumber (Roestia, 2008). Pengetahuan yang diperoleh peserta didik adlah penemuan bermakna yang ia dapatkan sendiri secara mandiri. Pada discovery learning, pembelajaran berpusat pada siswa. Guru hanya , mengarahkan peserta didik di awal pembelajaran. Guru memberikan tugas kepada peserta didik mencari mateeri yang berkaitan dengan klasifikasi makhluk hidup dan membuat rangkuman tentang materi tersebut.Dalar (2016) mengatakan bahwa peserta didik berusaha sendiri untuk mencari pemecahan masalah sehingga akan memberikan pengetahuan yang benar-benar bermakna.

Tahapan discovery learning terdiri dari stimulation, problemstatmen, data collection, data processing, verification dan generation (DJamarah, 2017). Ditahap stimulation guru memotivasi peserta didik. Pertanyaan dalam LKS mengandung kasus klasifikasi makhluk hidup yang menuntut peserta didik untuk berpikir analisis. Pada tahap problem statement, data colletion dan data processing. Kemampuan berpikir analisis peserta didik semakin di asa. Peserta didik mencari sendiri jawaban atas kasus yang diberikan dari berbagai sumber. Proses penemuan konsep dilakukan selama proses pembelajaran setelah peserta didik mendapatkan informasi pada pra pembelajaran seperti merangkum materi dan mencari informasi yang berkaitan dengan klasifikasi makhluk hidup dan pembelajaran dikelas. Tahapan pada discovery learning ini yang membuat peserta didik menemukan konsep secara mandiri. Hal ini didukung dengan penelitian Widiatnyana, (2014) bahwa pembelajaran discovery learning mampu meningkatkan pemahaman konsep IPA dan sikap ilmiah peserta didik SMA.

Menurut Putrayasa (2014), pembelajaran discovery learning sangat sesuai dengan peserta didik yang memiliki minat belajar tinggi, sehingga hasil belajar menjadi optimal. Faktor internal kedua adalah proses pembelajaran yang dialami setiap peserta didikberbeda-beda. Faktor internal lainnya adalah rasa ingin tahu peserta didik. Kemampuan berpikir analisis juga merupakan komponen dari hasil belajar. Hal ini sesuai dengan penelitian Kadri dan Rahmawati (2015) bahwa hasil belajar dengan pembelajaran discovery learning lebih baik dari pada pembelajaran konvensional pada klasifikasi makhluk hidup. 
Berdasarkan hasil penelitian ini, setelah di padukan model pembelajaran POGIL dan discovery learning terdapat peningkatan kemampuan berpikir analisis peserta didik. Tahapan POGIL membuat peserta didik mampu menemukan konsep di bantu dengan bimbingan guru sedangkan tahapan discovery learningpeserta didik menemukan konsep secara mandiri sehingga kedua pembelajaran ini mampu untuk mengembangkan kemampuan berpikir analisis peserta didik.

\section{UCAPAN TERIMA KASIH/PENGAKUAN/ACKNOWLEDGMENTS}

Penulis memberikan ucapan terima kasih/pengakuan/acknowledgments kepada pihak yang berkontribusi atas keterlaksanaan penelitian ini. Ucapan terimakasih ini diberikan kepada:

1. Kalsum Sehulawano, S.Pdl., M.Pd selaku Ketua STKIP Gotong Royong Masohi yang telah memberi motivasi dan dorongan dalam penelitian ini.

2. Kepala Sekolah SMA NKristen Trana yang telah membantu dan berkontribusi dalam pelaksanaan penelitian ini.

3. Marlen Sahureka, S.Si., M.Sc selaku Ketua LPPM yang telah berkontribusi dalam membantu pelaksanaan penelitian ini.

\section{SIMPULAN}

Berdasarkan hasil penelitian dan pembahasan pada kemampuan berpikir analisis peserta didik kelas X MIA SMA Kristen Trana melalui integrasi pembelajaran Process Oriented Guided Inquiry Learning (Pogil) dan Discovery Learning pada materi klasifikasi makhluk hidup dapat disimpulkan bahwa : Terjadi peningkatan kemampuan berpikir analisis peserta didik kelas X MIA SMA Kristen Trana melalui integrasi pembelajaran Process Oriented Guided Inquiry Learning (Pogil) dan Discovery Learning pada materi klasifikasi makhluk hidup. Berdasarkan hasil-hasil yang di temukan pada penelitian ini, maka saran yang diperoleh adalah Kepada guru biologi SMA agar lebih banyak menerapkan model pembelajaran POGIL dan Discovery Learning dalam pembelajaran di kelas untuk meningkatkan kemampuan berpikir analisis peserta didik.

\section{RUJUKAN}

Barthlow, M. J. 2015. The Effectiveness of Process Oriented Guided Inquiry Learning to Reduce Alternate Conceptions in Secondary Chemistry. (Disertasi) Liberty University.

Budiningsih (2015), Model Discovery LearningJakarta : Pustaka mandiri

De Gale,S., L.N. Boisselle.2015. The Effect of POGIL on Academic Performance anda Academic Confidence. The University of the West Indies. Science Education International. Vol 26, Issue I, 56-67.

Hamdayana, J. 2016. Model dan Metode Pembelajaran Kreatif dan Berkarakter. Ghalia Indonesia, Bogor.

Hanson, D. 2016. Instructor's guide to processoriented-guided-inquiry learning. Lisle IL, Pacific Crest. 
http : // Journal.Linnes.ac.id/sju/index.php/chemined.

Hanson, D. 2016. Instructor's guide to processoriented-guided-inquiry learning. Lisle IL, Pacific Crest.

Kadri, Muhammad dan Rahmawati, Meika. (2015). Pengaruh Model Pembelajaran Discovery Learning Terhadap Hasil Belajar Siswa Pada Materi Pokok Suhu danKalor. Jurnal Ikatan Alumni Fisika Universitas Negeri Medan, 1 (1), 24611247

Kemendikbud.2016 Peraturan Menteri Pendidikan dan Kebudayaan tentang Implementasi kurikulum.

Maharani. Y.B \& hardini , I. I. A.2018 Penerapan Model Pembelajaran Discovery berbantuan benda konkret untuk meningkatkan hasil belajar IPA jurnal mitra pendidikan, 1 ( 5 ), 245-561

Maulidiawati, Soprodjo.2014.Keektifan Pembelajaran Kooperatif dengan Process Oriented Guided Inquiry pada hasil Belajar.Chemisy in Education 3 (2)

Moog, R. S. \& Spencer N.J. 2015. In Process Oriented Guided Inquiry Learning (POGIL). ACS Symposium Series. American Chemical Society, Washington DC.

Mulyasa. 2013. Pengembangan dan Implementasi Kurikulum 2013. Bandung : PT Remaja Rosdakarya.

Normaya, K. 2015. Kemampuan Berpikir Kritis dalam Pembelajaran Matematika dengan Menggunakan Model JUCAMA di Sekolah Menengah Pertama. Edu-Mat Jurnal Pendidikan Matematika. 3(1), 92-104. Retrieved from http://ppjp.unlam.ac.id/journal/index.php/edumat/article/view/634/542.

Sen,S.Yilmaz,A. 2015. The Effcts of Process Oriented Guided Inquiry Enviroment on student,Self Regulated Learning Skills.Problems of Education in the $21{ }^{\text {st }}$ Century. Volume 66

Sani . 2017. Pembelajaran Saintifik untuk Implementasi Kurikulum 2013. Jakarta : PT Bumi Aksara.

Taufina. 2017. Sumber Belajar Penunjang PLPG 2017. Jakarta : Kementrian Pendidikan Dan Kebudayaan Direktorat Jenderal Guru dan Tenaga Kependidikan

Taslim . 2016 Konsep dan Implementasi Kurikulum di Sekolah Dasar (Yogyakarta argSakarsa).

Widiawati, Ika. 2018. Upaya Meningkatkan Keterampilan Proses Sains Siswa Melalui Strategi Pembelajaran POGIL pada Materi Laju Reaksi Di Kelas XI SMA Negeri 36 Jakarta (Skripsi). Universitas Negeri Jakarta, Jakarta.

Yuliati, L. (2013). Efektivitas Bahan Ajar IPA Terpadu terhadap Kemampuan Berpikir Tingkat Tinggi Siswa SMP. Jurnal Pendidikan Fisika Indonesia, 9(1), 55-57. DOI: http://dx.doi.org/10.15294/jpfi.v9i1.2580. 